\title{
Kvikksølv som legemiddel
}

På 1700-tallet ble kvikksølv bredt akseptert som den mest effektive medisin mot venerisk sykdom. I samme periode ble imidlertid også indikasjonene for kvikksølv stadig utvidet og utviklet seg fra å være et nærmest spesifikt remedium for venerisk sykdom til å bli noe i nærheten av et panacea. Det ble brukt ikke bare mot venerisk sykdom, men også mot andre hudlidelser, tumorer, parasitter, obstipasjon og en rekke andre tilstander. I samme århundre begynte imidlertid kvikksølvforgiftning å prege spaltene i de medisinske tidsskriftene. Skepsisen mot kvikksølv gjorde seg gjeldende i stadig stigende grad utover på 1800-tallet. Dette fikk vind i seilene av den såkalte terapeutiske nihilisme, en holdning om at medisiner gjør mer skade enn gagn og at man derfor heller burde være terapeutisk avventende og hjelpe kroppen å helbrede seg selv. Mot slutten av 1800-tallet var dette igjen i ferd med å snu. Under er det Michael Skjelderup som tar til orde for $\varnothing k t$ bruk av kvikksølv (Tidsskrift for praktisk Medicin 1881; 1: 9-12).

\section{Nogle Ord om Kviksølv i den medicinske Terapi.}

\author{
Af M. Skjelderup.
}

Da omkring 40aarene den terapeutiske Nihilsme begyndte at gjøre sig bred og tilslut saaledes dominerede Medicinen, at ingen intelligent Praktiker turde være bekjendt at tro paa Virkningen af Medikamenter, var Kviksølvet et af de gamle gode Midler, som blev skrinlagt tilligemed andet obsolet Skrammel. Selv Englænderne, som dog i det længste beholdt sin terapeutiske Barnetro, og som især nødig vilde give Slip paa sine kjære «blue pills» og «grey powder» maatte i Længden ogsaa bøie sig for Skriget og dementere sine gamle Klassikere [...]. Selv i Syfilis begyndte man saa smaat at skose det, og Kirurgerne og Oftalmologerne, hos hvem det i det længste beholdt sin gamle Værdighed, mente ogsaa at kunne lade haant om sin gamle Ven. Nu, de Tider er dog atter forbi. Selv hos os har Merkuren i Syfilis overvundet vor ellers saa fortjenstfulde afdøde W. Boecks Anatema og med Glands indtaget sin fortjente Plads, og vore praktiske Øienlæger tvivler ikke længere om Calomels merkelige Virksomhed ved forskjellige inflammatoriske Tilstande i dette lille følsomme Organ. [...]

Af ovenstaaende korte Fremstilling tør formentlig fremgaa, at vi i Kviksølv har et Medikament, der i flere Tilfælde gjør en hurtig og paatagelig Nytte i forskjellige indre Sygdomme, og at den Mistro til Midlet, som vel oprindelig er udgaaet fra den overdrevne Anvendelse af det, bør vige Plads for en rigtig Vurderen af dette i mange Tilfælde ganske uerstattelige Lægemiddel. 